\title{
Spongiibacter marinus gen. nov., sp. nov., a halophilic marine bacterium isolated from the boreal sponge Haliclona sp. 1
}

Ingeborg Graeber, ${ }^{1}$ Ines Kaesler, ${ }^{1}$ Martin S. Borchert, ${ }^{2}$ Ralf Dieckmann, ${ }^{3}$ Thomas Pape, ${ }^{4} \dagger$ Rudi Lurz, ${ }^{5}$ Preben Nielsen, ${ }^{6}$ Hans von Döhren, ${ }^{7}$ Walter Michaelis ${ }^{4}$ and Ulrich Szewzyk ${ }^{1}$

Correspondence Ingeborg Graeber i.graeber@web.de

\author{
${ }^{1}$ Berlin University of Technology, Environmental Microbiology Group, Franklinstrasse 29, Sekr. \\ FR 1-2, D-10587 Berlin, Germany \\ ${ }^{2}$ Hamburg University of Technology, Technical Microbiology, Kasernenstrasse 12, D-21073 \\ Hamburg, Germany \\ ${ }^{3}$ Anagnostec GmbH, Am Mühlenberg 11, D-14476 Potsdam-Golm, Germany \\ ${ }^{4}$ University of Hamburg, Institute of Biogeochemistry and Marine Chemistry, Bundesstrasse 55, \\ D-20146 Hamburg, Germany \\ ${ }^{5}$ Max-Planck Institute for Molecular Genetics, Ihnestrasse 63-73, D-14195 Berlin, Germany \\ ${ }^{6}$ Novozymes A/S, Bacterial screening, Krogshøjvej 36, DK-2880 Bagsværd, Denmark \\ ${ }^{7}$ Berlin University of Technology, Biochemistry and Molecular Biology Group, Franklinstrasse 29, \\ Sekr. OE2, D-10587 Berlin, Germany
}

\begin{abstract}
Strain $\mathrm{HAL}_{40 \mathrm{~b}^{\top}}$ was isolated from the marine sponge Haliclona sp. 1 collected at the Sula Ridge off the Norwegian coast and characterized by physiological, biochemical and phylogenetic analyses. The isolate was a small rod with a polar flagellum. It was aerobic, Gram-negative and oxidase- and catalase-positive. Optimal growth was observed at $20-30{ }^{\circ} \mathrm{C}, \mathrm{pH} 7-9$ and in $3 \%$ $\mathrm{NaCl}$. Substrate utilization tests were positive for arabinose, Tween 40 and Tween 80 . Enzyme tests were positive for alkaline phosphatase, esterase lipase (C8), leucine arylamidase, acid phosphatase, naphthol-AS-Bl-phosphohydrolase and $N$-acetyl- $\beta$-glucosaminidase. The predominant cellular fatty acid was $\mathrm{C}_{17: 1} \omega 8$, followed by $\mathrm{C}_{17: 0}$ and $\mathrm{C}_{18: 1} \omega 7$. Analysis by matrix-assisted laser desorption/ionization time-of-flight MS was used to characterize the strain, producing a characteristic low-molecular-mass protein pattern that could be used as a fingerprint for identification of members of this species. The DNA G+C content was $69.1 \mathrm{~mol} \%$.

Phylogenetic analysis supported by $16 \mathrm{~S}$ rRNA gene sequence comparison classified the strain as a member of the class Gammaproteobacteria. Strain $\mathrm{HAL} 40 \mathrm{~b}^{\top}$ was only distantly related to other marine bacteria including Neptunomonas naphthovorans and Marinobacter daepoensis (type strain sequence similarity $>90 \%$ ). Based on its phenotypic, physiological and phylogenetic characteristics, it is proposed that the strain should be placed into a new genus as a representative of a novel species, Spongiibacter marinus gen. nov., sp. nov.; the type strain of Spongiibacter marinus is $\mathrm{HAL}_{40 b^{\top}}\left(=\mathrm{DSM} 17750^{\top}=\right.$ CCUG $\left.54896^{\top}\right)$.
\end{abstract}

†Present address: Research Center Ocean Margins, University of Bremen, Klagenfurter Strasse, D-28359 Bremen, Germany.

Abbreviations: FAMEs, fatty acid methyl esters; MALDI-TOF, matrixassisted laser desorption/ionization time-of-flight.

The GenBank/EMBL/DDBJ accession number for the 16S rRNA gene sequence of strain HAL40b ${ }^{\top}$ is $A M 117932$.

A MALDI-TOF MS profile showing characteristic peaks and fatty acid composition data of Spongiibacter marinus $\mathrm{HAL} \mathrm{Ob}^{\top}$ are available as supplementary material with the online version of this paper.
In the last few years, interest has focussed on the analysis of microbial populations in different marine habitats as well as on marine bacteria as sources of natural products (Dobretsov et al., 2006; Piel, 2006; Taylor et al., 2007). In addition to investigations of the bacterial assemblage from coastal regions (Kan et al., 2006), the open sea (Ghiglione et al., 2005), deepsea areas (DeLong et al., 2006) and from sediments (Edlund et al., 2006), marine eukaryotes like algae (Croci et al., 2006) and invertebrates (Holmström \& Kjelleberg, 1999; Sfanos et al., 2005) have also been targets for analysis. 
Marine sponges have attracted attention specifically as they often harbour a diverse range of bacteria either resident in the mesohyl of the sponge or transiently within the channel system, where rapid exchange of surrounding water occurs. Microbial communities have been analysed in a number of marine sponges originating mostly from Mediterranean, tropical and temperate regions (Webster \& Hill, 2001; Webb \& Maas, 2002; Fieseler et al., 2004; Taylor et al., 2004); cold-water sponges (Althoff et al., 1998; Thiel et al., 2002; Webster et al., 2004) have rarely been examined. Based on cultivation-independent methods, a wide spectrum of bacteria has been shown to be in close association with the sponge host with representatives encompassing the bacilli, high- $\mathrm{G}+\mathrm{C}$-containing Gram-positive bacteria, Bacteroidetes, Acidobacteria, Actinobacteria, Planctomycetes and Verrucomicrobia, as well as proteobacteria (Webster et al., 2001; Hentschel et al., 2002). Cultivation and isolation of individual strains from sponges have revealed that proteobacteria are a major component of the bacterial community; in particular, gamma- and alphaproteobacteria have been found to be abundant (De Rosa et al., 2000; Hentschel et al., 2001; Lafi et al., 2005).

Our research objects were boreal sponges of the class Demospongiae and, among them, the sponge Haliclona sp. 1 was collected from a depth of approximately $300 \mathrm{~m}$ at the Sula Ridge, a deep cold-water reef complex stretching along the mid-Norwegian coast. A number of bacteria (183; data not shown) was isolated from this sponge, most of which were affiliated to the classes Gammaproteobacteria and Alphaproteobacteria (Dieckmann et al., 2005; and data not shown). The strain described here represents a taxon that has been isolated only from Haliclona, not from other coldwater sponge species, and is only distantly related to members of the Gammaproteobacteria with validly published names.

Sampling was performed with a manned submersible, enabling precise selection of the desired sponges with minimal damage to the reef. Sections of the sponge were homogenized, serially diluted in sterile seawater and spread on marine broth agar (MBA 2216; Difco). The plates were kept cold $\left(8{ }^{\circ} \mathrm{C}\right)$ during the initial cultivation; purification to single colonies was performed at room temperature.

Colony morphology was analysed on MBA by stereomicroscopy. Colonies were $0.2-0.4 \mathrm{~mm}$ after 5 days of incubation at room temperature, beige, nearly transparent and possessed a circular convex shape and a shiny surface. Cellular morphology and motility were examined by phase-contrast microscopy from wet mounts of bacterial cells on agar-coated slides grown in liquid cultures for 2 days at room temperature and by transmission electron microscopy with a CM100 (Philips) equipped with a FastScan $1 \mathrm{k} \times 1 \mathrm{k}$ CCD camera (TVIPS). Cells were grown for 5 days in sterile filtered marine broth, concentrated by centrifugation and either negatively stained by uranyl acetate according to Steven et al. (1988) (Fig. 1a) or embedded in epoxy resin according to Spurr (1969) for the

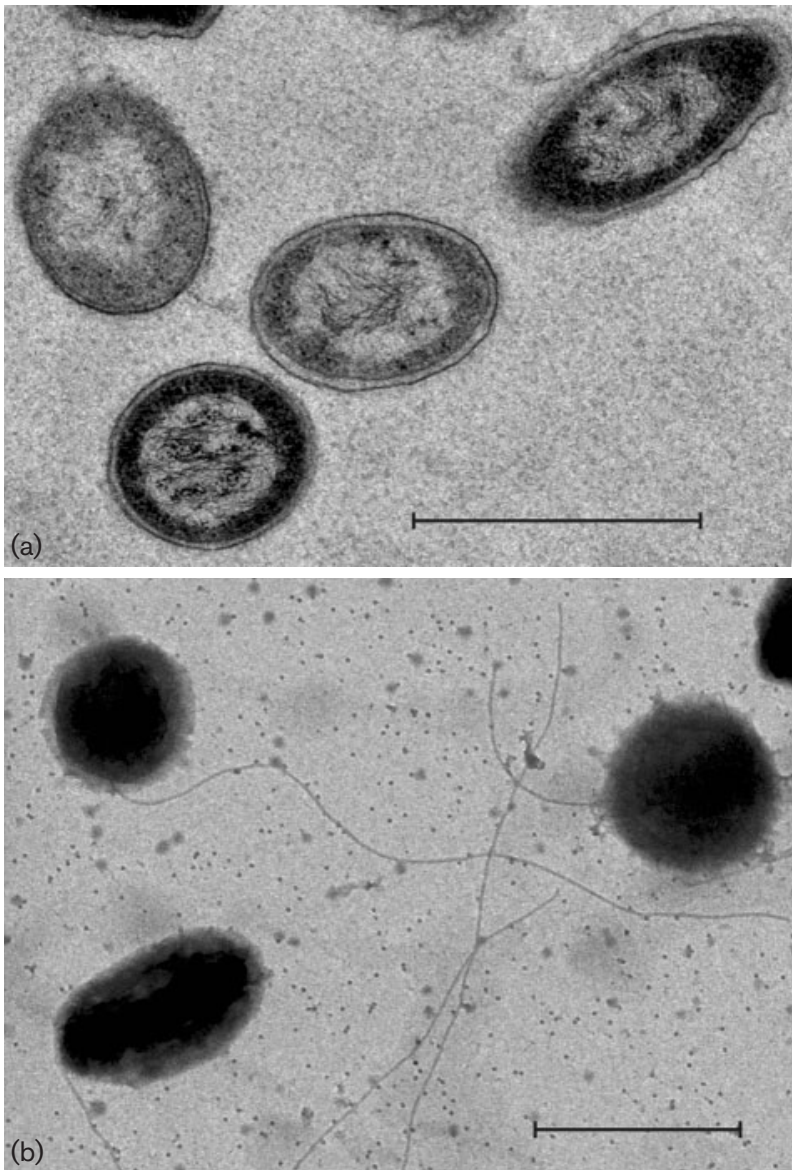

Fig. 1. Transmission electron micrographs of strain $\mathrm{HAL} 40 \mathrm{~b}^{\top}$. (a) Cell shape and nuclear material shown after ultrathin sectioning; (b) cell shape and single polar flagellum shown after negative staining with $0.8 \%$ uranyl acetate. Bars, $1 \mu \mathrm{m}$.

examination of ultrathin sections (Fig. 1b). The analysis revealed short, motile rods, $1.0-2.0 \times 0.4-0.6 \mu \mathrm{m}$, with a single polar flagellum.

During the isolation campaign, whole-cell MS analysis [matrix-assisted laser desorption/ionization time-of-flight (MALDI-TOF) MS] in the mass range $2-20 \mathrm{kDa}$ was used to characterize and deduplicate strains and to identify unique isolates. Colonies of cells growing on MBA plates were transferred directly onto a stainless steel sample plate and mixed immediately with $1 \mu \mathrm{l}$ matrix solution $[10 \mathrm{mg}$ 2,5-dihydroxybenzoic acid $\mathrm{ml}^{-1}$ in acetonitrile/methanol/ water $(1: 1: 1)$ and $0.3 \%$ trifluoroacetic acid]. The sample/ matrix mixture was allowed to air dry prior to analysis. MS measurements were performed on a Voyager DEPRO time-of-flight MS (Applied Biosystems) according to Dieckmann et al. (2005). The SARAMIS software (AnagnosTec) was used for archiving and classification of mass spectra. Information on the SARAMIS system and database can be obtained from http://www.anagnostec.eu. The majority of peaks clustered between masses of 2 and 
$10 \mathrm{kDa}$. The method revealed several clusters of bacteria representing the taxonomic groups of gamma- and alphaproteobacteria, bacilli and sphingobacteria (Dieckmann et al., 2005). Such a composition of the culturable microbial community is not unusual for a marine sponge (Hentschel et al., 2001; Taylor et al., 2007; and references therein). Sponges often harbour a huge mass of bacteria in their mesohyl, where they either reside permanently in parasitic, commensalistic or symbiotic relationships or are part of the quick turnover with the surrounding seawater. Strain HAL $40 \mathrm{~b}^{\mathrm{T}}$ was detected on nutrient-rich medium as a very slowly growing gammaproteobacterium. With the methods used, its status in the sponge and its frequency of occurrence could not be determined. The MALDI-TOF MS intact-cell profile of HAL40b ${ }^{\mathrm{T}}$ (see Supplementary Fig. S1 available in IJSEM Online) with its characteristic lowmolecular-mass protein pattern was found to be unique when compared with mass data obtained from all other strains isolated during the campaign by using the SARAMIS software (data not shown).

Sequence determination of strain HAL $40 \mathrm{~b}^{\mathrm{T}}$ was done by amplification of the 16S rRNA gene region by PCR using primers $16 \mathrm{Sf}$ and $16 \mathrm{Sr}$. Standard primers 357F, 530R, $1100 \mathrm{~F}, 1230 \mathrm{~F}$ and $1390 \mathrm{R}$ were used for sequencing the nearly full-length $16 \mathrm{~S}$ rRNA gene (1452 bp) according to Escherichia coli standard positions (Brosius et al., 1978). Sequence data were analysed with an ABI PRISM 310 Genetic Analyzer (PE Applied Biosystems). Phylogenetic affiliation was performed with the ARB software (Ludwig et al., 2004), in addition to sequence comparison to the EMBL/GenBank nucleotide sequence databases. The phylogenetic tree was calculated with 16S rRNA gene sequences (1409 bp; E. coli positions 51-1460) by using the neighbour-joining (Jukes-Cantor correction), maximumparsimony and maximum-likelihood methods implemented in ARB. Different filters were used for calculations. Data revealed that the strain belonged to the class Gammaproteobacteria. This class represents a large phylogenetic group of species found in most marine environments, which are generally well represented in culturing assays. The sequence was aligned against those of a number of close relatives identified from a BLAST query of the GenBank database. Highest sequence similarities (99\%) were found to a planktonic strain RED77 (Pinhassi \& Berman, 2003; GenBank accession no. AY136133), isolated from Red Sea dilution cultures (with only $770 \mathrm{bp}$ available for alignment) and to an isolate from the sea surface microlayer obtained from a coastal environment (Agogué et al., 2005a, b; GenBank accession no. AY576729). An epibiotic bacterium originating from diatoms in natural coastal waters showed $96 \%$ sequence similarity (Kaczmarska et al., 2005; GenBank accession no. AY548769). The characterizations of these bacteria were restricted to only morphological and/or phylogenetic analysis; no biochemical or physiological data were determined. Also, $96 \%$ similarity was described for strain NEP4, which was isolated from marine coastal sediment (Maeda et al., 2005; GenBank accession no. AB212803). Lower similarity (91\%) was found to a marine strain with specific degrading capacities (GenBank accession no. AB086227). Uncultured bacterial sequences (GenBank accession nos DQ395870, AF468306 and DQ906761) from marine habitats clustered with sequence similarities of 90-93\%. A number of Pseudomonas strains were distantly affiliated to $\mathrm{HAL} 40 \mathrm{~b}^{\mathrm{T}}$, with sequence similarities of $89 \%$. The closest relatives to strain HAL $40 b^{T}$ with validly published names included the type strains of Marinobacter daepoensis (Yoon et al., 2004) and Neptunomonas naphthovorans (Hedlund et al., 1999), with sequence similarities of about $90 \%$. A phylogenetic tree was constructed on the basis of these sequences (Fig. 2), revealing a branch for HAL $40 \mathrm{~b}^{\mathrm{T}}$ that was separate from these two type strains and from the cluster of Pseudomonas strains.

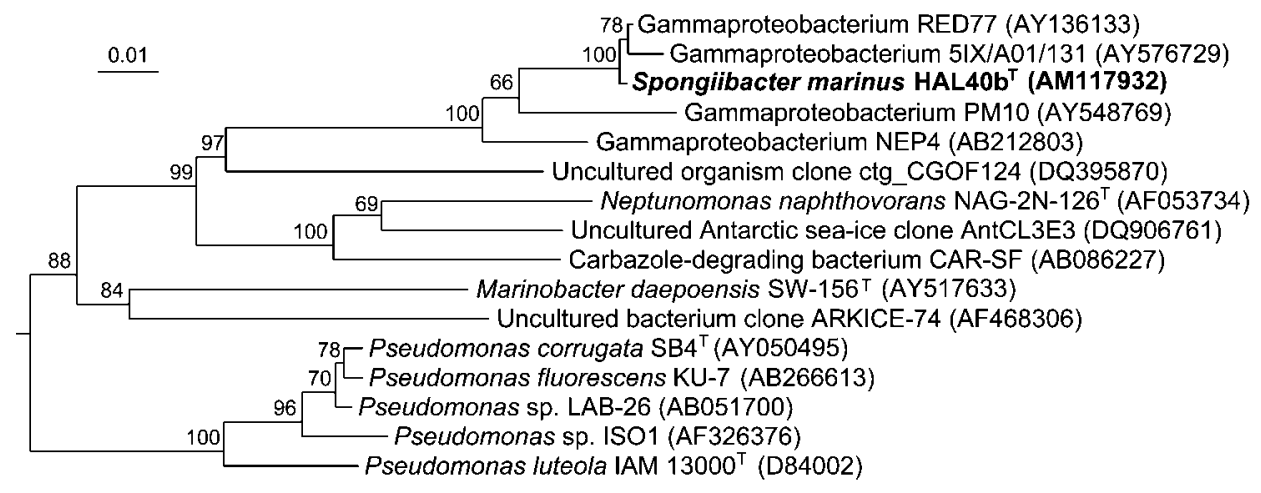

Fig. 2. Phylogenetic tree based on $16 \mathrm{~S}$ rRNA gene sequences of strain $\mathrm{HAL} 40 \mathrm{~b}^{\top}$ and related gammaproteobacteria. The tree was calculated with the maximum-parsimony method. The short sequence of strain RED77 (770 bp) was added to the calculated tree by the quick add function of ARB. Numbers given at branch nodes indicate bootstrap values (\%) for 1000 replicates. Accession numbers of the sequences are shown. Bar, $1 \%$ sequence divergence. Thermotoga maritima MSB8 ${ }^{\top}$ (GenBank accession no. M21774) was used as an outgroup (not shown). 
Temperature range and optimum for growth of strain HAL $40 b^{\mathrm{T}}$ were tested at $2-45{ }^{\circ} \mathrm{C}$ in marine broth (Difco). The $\mathrm{pH}$ range and optimum for growth were determined at $\mathrm{pH} 5-10$ at $30{ }^{\circ} \mathrm{C}$ in a medium containing peptone $(1 \mathrm{~g}$ $\left.\mathrm{l}^{-1}\right)$, yeast extract $\left(5 \mathrm{~g} \mathrm{l}^{-1}\right)$ and $3 \%(\mathrm{w} / \mathrm{v}) \mathrm{NaCl}$. Salt concentration range and optimum for growth were investigated in $0-9 \% \mathrm{NaCl}$ at $30{ }^{\circ} \mathrm{C}$. Comparative analysis of HAL40 $\mathrm{b}^{\mathrm{T}}$ with $M$. daepoensis and $N$. naphthovorans revealed a number of differences (Table 1). Cells of $\mathrm{HAL}_{40 \mathrm{~b}}{ }^{\mathrm{T}}$ were remarkably smaller and the temperature and $\mathrm{pH}$ growth profiles differed greatly. Growth of strain HAL40b ${ }^{\mathrm{T}}$ occurred at $10-40{ }^{\circ} \mathrm{C}$ and was best at $20-30{ }^{\circ} \mathrm{C}$. The $\mathrm{pH}$ range for growth was 6.5-9.5 and maximum growth rates were observed at $\mathrm{pH} 7-9$. Growth was observed in media containing $\mathrm{NaCl}$ concentrations of 1$7 \%$, with maximum growth at $3 \% \mathrm{NaCl}$, highlighting the marine origin of the bacterium. However, the salt tolerance was higher for $M$. daepoensis $(18 \% \mathrm{NaCl})$.

Tests for the oxidation of various substrates were carried out using microplates (Biolog) for Gram-negative bacteria and API 20E and API ZYM test kits (bioMérieux) according to the manufacturers' recommendations. After a growth period of 4 days in marine broth at $18{ }^{\circ} \mathrm{C}$, cells were resuspended in artificial seawater (Lyman \& Fleming, 1940 ) for the Biolog test and in $0.6 \% \mathrm{NaCl}$ for the API ZYM and API 20E kits. Test strips from API ZYM and API 20E kits were read after 2 days and Biolog plates were inoculated for up to 5 days. Catalase and oxidase activities were tested with test strips from Merck, according to the manufacturer's manual. Tests were performed in duplicate. HAL $40 \mathrm{~b}^{\mathrm{T}}$ showed positive activity for alkaline and acid phosphatase, esterase (C4), leucine arylamidase, acid phosphatase, naphthol-AS-BI-phosphohydrolase,
$N$-acetyl- $\beta$-glucosaminidase and esterase lipase (C8). The strain was able to use arabinose, Tween 40 and Tween 80 for growth. HAL40 ${ }^{\mathrm{T}}, M$. daepoensis and $N$. naphthovorans were all Gram-negative, motile by means of a single polar flagellum and oxidase- and catalase-positive. They showed similar behaviour in the API ZYM, API 20E and Biolog tests (Table 1). However, limited substrate and enzyme data were available for $N$. naphthovorans, which made a detailed biochemical comparison with this strain impossible. Some physiological data were available for strain NEP4 (Maeda et al., 2005). This strain was also Gramnegative, motile, and oxidase- and catalase-positive and showed similar growth to HAL $40 \mathrm{~b}^{\mathrm{T}}$ at $\mathrm{pH}$ 7-9. In contrast to strain $\mathrm{HAL}_{40 \mathrm{~b}^{\mathrm{T}}}$, strain NEP4 grew at a higher temperature range $\left(20-40{ }^{\circ} \mathrm{C}\right)$ and was able to utilize acetate, pyruvate, propionate, succinate, lactate, tetraethylene glycol and polyethylene glycol 300 as sole carbon sources.

Anaerobic growth was tested on MBA in glass tubes under anaerobic conditions $\left(80 \% \mathrm{~N}_{2} / 20 \% \mathrm{CO}_{2}\right)$ and by using the Anaerocult System (Merck). Growth of HAL40b ${ }^{\mathrm{T}}$ was strictly aerobic, although the strain survived for 3 weeks without gaseous oxygen and resumed growth after aeration.

Analysis of the DNA G + C content was done at the DSMZ (Braunschweig, Germany). Calibration of the method was performed using non-methylated lambda-DNA possessing a known G $+\mathrm{C}$ content of $49.9 \mathrm{~mol} \%$ (Mesbah et al., 1989), as well as three genomic DNAs for which complete genome sequences have been published, including Bacillus subtilis DSM 402 ( $\mathrm{G}+\mathrm{C}$ content $43.5 \mathrm{~mol} \%)$, Xanthomonas campestris pv. campestris DSM $3586^{\mathrm{T}}(65.1 \mathrm{~mol} \%)$ and Streptomyces violaceoruber DSM 40783 (72.1 mol\%).

Table 1. Phenotypic and physiological characteristics of strain $\mathrm{HAL} 40 \mathrm{~b}^{\top}$ and the type strains of two related organisms

Data for M. daepoensis SW-156 ${ }^{\mathrm{T}}$ and N. naphthovorans NAG-2N-126 ${ }^{\mathrm{T}}$ were taken from Yoon et al. (2004) and Hedlund et al. (1999), respectively. Cells of all three strains were motile short rods, positive for alkaline and acid phosphatase, oxidase and catalase. HAL40b ${ }^{\mathrm{T}}$ and M. daepoensis SW$156^{\mathrm{T}}$ are positive for esterase (C4), leucine arylamidase, acid phosphatase, naphthol-AS-BI-phosphohydrolase and $N$-acetyl- $\beta$-glucosaminidase activities and hydrolysis of Tween 40 and Tween 80; these data were not reported for N. naphthovorans NAG-2N-126 ${ }^{\mathrm{T}}$. ND, No data available.

\begin{tabular}{|c|c|c|c|}
\hline Characteristic & ${\text { HAL } 40 b^{T}}^{T}$ & M. daepoensis SW-156 ${ }^{\mathrm{T}}$ & $\begin{array}{c}\text { N. naphthovorans NAG-2N- } \\
\qquad 126^{\mathrm{T}}\end{array}$ \\
\hline Colony morphology & Circular, beige, $0.2-0.4 \mathrm{~mm}^{*}$ & $\begin{array}{c}\text { Cream, smooth, circular to slightly } \\
\text { irregular, low-convex }\end{array}$ & Beige or light brown \\
\hline Cell size $(\mu \mathrm{m})$ & $1.0-2.0 \times 0.4-0.6$ & $1.5-3.0 \times 0.6-0.8$ & $2.0-3.0 \times 0.7-0.9$ \\
\hline $\begin{array}{l}\text { Temperature range for growth } \\
\text { (optimum) }\left({ }^{\circ} \mathrm{C}\right)\end{array}$ & $10-40(20-30)$ & No growth at 4 ; maximum $45(30-37)$ & $4-24(\mathrm{ND})$ \\
\hline $\mathrm{pH}$ range for growth (optimum) & $6.5-9.5(7-9)$ & Minimum $5.5(7-8)$ & $6.5-8.5(7.5)$ \\
\hline $\begin{array}{l}\text { Salt tolerance for growth (optimum) } \\
(\% \mathrm{w} / \mathrm{v})\end{array}$ & $1-7(3)$ & Maximum $18(2-6)$ & $1.75-7(\mathrm{ND})$ \\
\hline Esterase lipase (C8) & + & + & - \\
\hline Utilization of arabinose & + & ND & + \\
\hline DNA G $+C$ content $(\mathrm{mol} \%)$ & 69 & 57 & 46 \\
\hline
\end{tabular}

${ }^{\star}$ Diameter after 5 days incubation at room temperature. 
The DNA G+C content of isolate HAL40b ${ }^{\mathrm{T}}$ was $69.1 \mathrm{~mol} \%$ and, thus, clearly differed from those of both M. daepoensis SW-156 ${ }^{\mathrm{T}}$ (57 mol\%) and N. naphthovorans NAG-2N-126 ${ }^{\mathrm{T}}$ (46 mol\%).

Whole-cell fatty acid methyl esters (FAMEs) were obtained from washed cells by extraction and transesterification of $20 \mathrm{mg}$ freeze-dried cells with a mixture of trimethylchlorosilane/methanol $\left(1: 8, \mathrm{v} / \mathrm{v} ; 1 \mathrm{~h}, 75^{\circ} \mathrm{C}\right)$ and re-extraction with n-hexane. Compounds were analysed by GC and combined GC-MS. Quantification of individual compounds was achieved by adding $\mathrm{n}$-heneicosanoic acid methyl ester $\left(\mathrm{C}_{21: 0}\right)$ as an internal standard at a known concentration prior to GC analysis. FAMEs were identified by comparison of mass spectra and retention times with published data and/or reference compounds. Double-bond positions of monounsaturated FAMEs were determined from their dimethyldisulfide derivatives (Buser et al., 1983). Hydroxy fatty acids were analysed as their trimethylsilyl ether derivatives. For structural elucidations, monounsaturated FAMEs were converted to their saturated structural analogues by hydrogenation. Twenty-five fatty acids were present in the cell hydrolysate of HAL40b ${ }^{\mathrm{T}}$ in relative amounts of $>0.1 \%$ of total fatty acids and contained 11-19 carbon atoms (Supplementary Table S1). The most abundant fatty acid by far was heptadec-8enoic acid $\left(\mathrm{C}_{17: 1} \omega 8 ; 51.7 \%\right.$ total fatty acids) followed by heptadecanoic acid $\left(\mathrm{C}_{17: 0} ; 9.6 \%\right)$ and octadec-7-enoic acid $\left(\mathrm{C}_{18: 1} \omega 7 ; 7.8 \%\right)$. Strain HAL40b ${ }^{\mathrm{T}}$ exhibited a whole-cell fatty acid composition that was uncommon amongst members of the class Gammaproteobacteria. Detailed fatty acid distribution patterns of the closest phylogenetic relatives $\left(>90 \%\right.$ similarity) of $\mathrm{HAL}^{2} \mathrm{~b}^{\mathrm{T}}$ have been reported for only $M$. daepoensis SW $-156^{\mathrm{T}}$ so far. The two strains differed strongly in their fatty acid profiles; the major components found in $M$. daepoensis SW- $156^{\mathrm{T}}$ were $\mathrm{C}_{16: 0}(24.8 \%)$ and $\mathrm{C}_{18: 1} \omega 9(24.3 \%)$. Thus, the whole-cell fatty acid composition of strain HAL $40 \mathrm{~b}^{\mathrm{T}}$ corroborates the proposal of a novel species within a new genus.

Results of these phenotypic, biochemical and physiological analyses, together with the phylogenetic differences, clearly indicate that strain $\mathrm{HAL}_{40 \mathrm{~b}^{\mathrm{T}}}$ can be assigned to the Gammaproteobacteria, but not to a previously described bacterial genus in this class. It is proposed that it represents a novel species within a new genus: Spongiibacter marinus gen. nov., sp. nov.

\section{Description of Spongiibacter gen. nov.}

Spongiibacter (Spon.gi.i.bac'ter. L. fem. n. spongia sponge; N.L. masc. n. bacter a rod; N.L. masc. n. Spongiibacter a rod-shaped bacterium isolated from a sponge).

Gram-negative, rod-shaped bacteria. Motile by means of a polar flagellum. The genus belongs to the class Gammaproteobacteria based on phylogenetic analysis of $16 \mathrm{~S}$ rRNA gene sequences. Oxidase reaction is positive and catalase reaction weakly positive. Strictly aerobic. Halophilic. The type species is Spongiibacter marinus.

\section{Description of Spongiibacter marinus sp. nov.}

Spongiibacter marinus (ma.ri'nus. L. masc. adj. marinus of the sea, marine).

Characteristics are as above for the genus plus the following data. Cells are $1.0-2.0 \times 0.4-0.6 \mu \mathrm{m}$. Grows at $10-40{ }^{\circ} \mathrm{C}$ and $\mathrm{pH}$ 6.5-9.5, with optimum growth at $20-30{ }^{\circ} \mathrm{C}$ and $\mathrm{pH} 7-9 . \mathrm{NaCl}$ is required for growth; grows at $1-7 \% \mathrm{NaCl}$, with optimum growth at $3 \% \mathrm{NaCl}$. Positive for alkaline phosphatase, esterase, leucine arylamidase, acid phosphatase, naphthol-AS-BI-phosphohydrolase and $N$-acetyl- $\beta$ glucosaminidase activities. Hydrolyses Tween 40 and Tween 80. Utilizes arabinose as a carbon source. The predominant cellular fatty acid is $\mathrm{C}_{17: 1} \omega 8$.

The type strain is $\mathrm{HAL}_{40 \mathrm{~b}^{\mathrm{T}}}\left(=\mathrm{DSM} 17750^{\mathrm{T}}=\mathrm{CCUG}\right.$ $\left.54896^{\mathrm{T}}\right)$. The DNA $\mathrm{G}+\mathrm{C}$ content of the type strain is $69.1 \mathrm{~mol} \%$.

\section{Acknowledgements}

This work was financially supported by the research program BOSMAN (03F0358B) from the Bundesministerium für Bildung und Forschung (BMBF), Germany. The captain and crews of the R/V Poseidon and the manned submersible Jago are warmly thanked for excellent collaboration during field-work. We thank Gabriele Meuser and Gerhild Lüder for valuable technical assistance and Friederike Hoffmann (University of Bremen, Germany) for taxonomic analysis of the sponge species. We gratefully acknowledge the contribution of Hans G. Trüper (University of Bonn, Germany) to the nomenclature of the novel bacterium.

\section{References}

Agogué, H., Casamayor, E. O., Bourrain, M., Obernosterer, I., Joux, F., Herndl, G. J. \& Lebaron, P. (2005a). A survey on bacteria inhabiting the sea surface microlayer of coastal ecosystems. FEMS Microbiol Ecol 54, 269-280.

Agogué, H., Joux, F., Obernosterer, I. \& Lebaron, P. (2005b). Resistance of marine bacterioneuston to solar radiation. Appl Environ Microbiol 71, 5282-5289.

Althoff, K., Schütt, C., Steffen, R., Batel, R. \& Müller, W. E. G. (1998). Evidence for a symbiosis between bacteria of the genus Rhodobacter and the marine sponge Halichondria panicea: harbor also for putatively toxic bacteria? Mar Biol 130, 529-536.

Brosius, J., Palmer, M. L., Kennedy, P. J. \& Noller, H. F. (1978). Complete nucleotide sequence of a $16 \mathrm{~S}$ ribosomal RNA gene from Escherichia coli. Proc Natl Acad Sci U S A 75, 4801-4805.

Buser, H. R., Arn, H., Guerin, P. \& Rauscher, S. (1983). Determination of double bond position in mono-unsaturated acetates by mass spectrometry of dimethyl disulfide adducts. Anal Chem 55, 818-822.

Croci, L., Cozzi, L., Suffredini, E., Ciccaglioni, G., Toti, L., Milandri, A., Ceredi, A., Benzi, A. \& Poletti, R. (2006). Characterization of microalgae and associated bacteria collected from shellfish harvesting areas. Harmful Algae 5, 266-274.

De Rosa, S., Milone, A., Kujumgiev, A., Stefanov, K., Nechev, I. \& Popov, S. (2000). Metabolites from a marine bacterium Pseudomonas/ Alteromonas, associated with the sponge Dysidea fragilis. Comp Biochem Physiol B Biochem Mol Biol 126, 391-396.

DeLong, E. F., Preston, C. M., Mincer, T., Rich, V., Hallam, S. J., Frigaard, N. U., Martinez, A., Sullivan, M. B., Edwards, R. \& other 
authors (2006). Community genomics among stratified microbial assemblages in the ocean's interior. Science 311, 496-503.

Dieckmann, R., Graeber, I., Kaesler, I., Szewzyk, U. \& von Döhren, H. (2005). Rapid screening and dereplication of bacterial isolates from marine sponges of the Sula Ridge by intact-cell-MALDI-TOF mass spectrometry (ICM-MS). Appl Microbiol Biotechnol 67, 539-548.

Dobretsov, S., Dahms, H. U. \& Qian, P. Y. (2006). Inhibition of biofouling by marine microorganisms and their metabolites. Biofouling 22, 43-54.

Edlund, A., Soule, T., Sjöling, S. \& Jansson, J. K. (2006). Microbial community structure in polluted Baltic Sea sediments. Environ Microbiol 8, 223-232.

Fieseler, L., Horn, M., Wagner, M. \& Hentschel, U. (2004). Discovery of a novel candidate phylum 'Poribacteria' in marine sponges. Appl Environ Microbiol 70, 3724-3732.

Ghiglione, J.-F., Larcher, M. \& Lebaron, P. (2005). Spatial and temporal scales of variation in bacterioplankton community structure in the NW Mediterranean Sea. Aquat Microb Ecol 40, 229-240.

Hedlund, B. P., Geiselbrecht, A. D., Bair, T. J. \& Staley, J. T. (1999). Polycyclic aromatic hydrocarbon degradation by a new marine bacterium, Neptunomonas naphthovorans gen. nov., sp. nov. Appl Environ Microbiol 65, 251-259.

Hentschel, U., Schmid, M., Wagner, M., Fieseler, L., Gernert, C. \& Hacker, J. (2001). Isolation and phylogenetic analysis of bacteria with antimicrobial activities from the Mediterranean sponges Aplysina aerophoba and Aplysina cavernicola. FEMS Microbiol Ecol 35, 305-312.

Hentschel, U., Hopke, J., Horn, M., Friedrich, A. B., Wagner, M., Hacker, J. \& Moore, B. S. (2002). Molecular evidence for a uniform microbial community in sponges from different oceans. Appl Environ Microbiol 68, 4431-4440.

Holmström, C. \& Kjelleberg, S. (1999). Marine Pseudoalteromonas species are associated with higher organisms and produce biologically active extracellular agents. FEMS Microbiol Ecol 30, 285-293.

Kaczmarska, I., Ehrmann, J. M., Bates, S. S., Green, D. H., Léger, C. \& Harris, J. (2005). Diversity and distribution of epibiotic bacteria on Pseudo-nitzschia multiseries (Bacillariophyceae) in culture, and comparison with those on diatoms in native seawater. Harmful Algae 4, 725-741.

Kan, J. J., Wang, K. \& Chen, F. (2006). Temporal variation and detection limit of an estuarine bacterioplankton community analyzed by denaturing gradient gel electrophoresis (DGGE). Aquat Microb Ecol 42, 7-18.

Lafi, F. F., Garson, M. J. \& Fuerst, J. A. (2005). Culturable bacterial symbionts isolated from two distinct sponge species (Pseudoceratina clavata and Rhabdastrella globostellata) from the Great Barrier Reef display similar phylogenetic diversity. Microb Ecol 50, 213-220.

Ludwig, W., Strunk, O., Westram, R., Richter, L., Meier, H., Yadhukumar, Buchner, A., Lai, T., Steppi, S. \& other authors (2004). ARB: a software environment for sequence data. Nucleic Acids Res 32, 1363-1371.

Lyman, J. \& Fleming, R. H. (1940). Composition of sea water. J Mar Res 3, 134-146.
Maeda, T., Hayakawa, K., You, M., Sasaki, M., Yamaji, Y., Furushita, M. \& Shiba, T. (2005). Characteristics of nonylphenol polyethoxylatedegrading bacteria isolated from coastal sediments. Microbes Environ 20, 253-257.

Mesbah, M., Premachandran, U. \& Whitman, W. B. (1989). Precise measurement of the $\mathrm{G}+\mathrm{C}$ content of deoxyribonucleic acid by highperformance liquid chromatography. Int J Syst Bacteriol 39, 159-167.

Piel, J. (2006). Bacterial symbionts: prospects for the sustainable production of invertebrate-derived pharmaceuticals. Curr Med Chem 13, 39-50.

Pinhassi, J. \& Berman, T. (2003). Differential growth response of colony-forming alpha- and gamma-proteobacteria in dilution culture and nutrient addition experiments from Lake Kinneret (Israel), the eastern Mediterranean Sea, and the Gulf of Eilat. Appl Environ Microbiol 69, 199-211.

Sfanos, K. A. S., Harmody, D. K., Dang, P., Ledger, A., Pomponi, S. A., McCarthy, P. J. \& Lopez, J. V. (2005). A molecular systematic survey of cultured microbial associates of deep-water marine invertebrates. Syst Appl Microbiol 28, 242-264.

Spurr, A. R. (1969). A low-viscosity epoxy resin embedding medium for electron microscopy. J Ultrastruct Res 26, 31-42.

Steven, A. C., Trus, B. L., Maizel, J. V., Unser, M., Parry, D. A. D., Wall, J. S., Hainfeld, J. F. \& Studier, F. W. (1988). Molecular substructure of a viral receptor-recognition protein. The gp17 tail-fiber of bacteriophage T7. J Mol Biol 200, 351-365.

Taylor, M. W., Schupp, P. J., Dahllöf, I., Kjelleberg, S. \& Steinberg, P. D. (2004). Host specificity in marine sponge-associated bacteria, and potential implications for marine microbial diversity. Environ Microbiol 6, 121-130.

Taylor, M. W., Radax, R., Steger, D. \& Wagner, M. (2007). Spongeassociated microorganisms: evolution, ecology, and biotechnological potential. Microbiol Mol Biol Rev 71, 295-347.

Thiel, V., Blumenberg, M., Hefter, J., Pape, T., Pomponi, S., Reed, J., Reitner, J., Wörheide, G. \& Michaelis, W. (2002). A chemical view of the most ancient metazoa - biomarker chemotaxonomy of hexactinellid sponges. Naturwissenschaften 89, 60-66.

Webb, V. L. \& Maas, E. (2002). Sequence analysis of $16 \mathrm{~S}$ rRNA gene of cyanobacteria associated with the marine sponge Mycale (Carmia) hentscheli. FEMS Microbiol Lett 207, 43-47.

Webster, N. S. \& Hill, R. T. (2001). The culturable microbial community of the Great Barrier Reef sponge Rhopaloeides odorabile is dominated by an $\alpha$-proteobacterium. Mar Biol 138, 843-851.

Webster, N. S., Wilson, K. J., Blackall, L. L. \& Hill, R. T. (2001). Phylogenetic diversity of bacteria associated with the marine sponge Rhopaloeides odorabile. Appl Environ Microbiol 67, 434-444.

Webster, N. S., Negri, A. P., Munro, M. M. H. G. \& Battershill, C. N. (2004). Diverse microbial communities inhabit Antarctic sponges. Environ Microbiol 6, 288-300.

Yoon, J.-H., Yeo, S.-H., Kim, I.-G. \& Oh, T.-K. (2004). Marinobacter flavimaris sp. nov. and Marinobacter daepoensis sp. nov., slightly halophilic organisms isolated from sea water of the Yellow Sea in Korea. Int J Syst Evol Microbiol 54, 1799-1803. 